Original Article

\title{
Homeopathic use of modern drugs: therapeutic application of the organism paradoxical reaction or rebound effect
}

\author{
Marcus Zulian Teixeira \\ Faculty of Medicine, Universidade de São Paulo (FMUSP), São Paulo, Brazil
}

\begin{abstract}
When Samuel Hahnemann systematized homeopathy and the effects of drugs on the state of human health, he described the primary action of drugs and the following secondary and opposite reaction of the organism. Seeking to apply this secondary action or vital reaction of the organism as therapeutic method, he postulated the principle of similitude, i.e. the prescription to ill individuals of drugs that cause similar symptoms in the healthy (similia similibus curentur). In modern pharmacology, secondary action (vital reaction) of drugs is known as rebound effect or paradoxical reaction of the organism. It has been observed after discontinuation of several classes of palliative (enantiopathic) drugs, namely those that act according to the principle of contraries (contraria contrariis curentur). Although in this case it is associated with severe and fatal iatrogenic events, rebound effect might awaken a healing reaction when the very same drug is employed according to the principle of similitude. The validity of the principle of similitude is proved by scientific evidence on rebound effect, whereas conventional drugs primary (therapeutic, adverse and side) effects might be equated to pathogenetic manifestations and thus be homeopathically applied. For this purpose a homeopathic materia medica and repertory comprising 1,251 modern drugs was elaborated using the monographs described in The United States Pharmacopeia Dispensing Information as source (www.newhomeopathicmedicines.com). Thus, the therapeutic range of homeopathy is broadened through the addition of hundreds of new medicines that might be employed in every kind of disease including countless modern clinical syndromes.
\end{abstract}

Keywords: Homeopathy; Mechanism of Action of Homeopathic Medicines; Pharmacodynamic Action of Homeopathic Medicines; Homeopathic Medicines, New; Secondary Effect; Rebound Effect; Paradoxical Reaction.

\section{Introduction}

In a work considered foundational for homeopathy entitled Essay on a new principle to ascertain the healing powers of drugs [1], Samuel Hahnemann discusses the pharmacological properties of tens of medicines used at that time, and describes their direct primary action on the body manifested through a series of pathogenetic effects or symptoms, as well as the subsequent indirect secondary action developed by the organism to neutralize the former. Hahnemann attributes the healing power of drugs to the latter. To illustrate:

Arsenic (Arsenicum album). Direct primary action: tendency to excite spasm in the blood vessels and chills, in daily paroxysms; continual use of large doses gradually causes an almost constant febrile state; decrease of the tonus of the muscular fiber and the sensitiveness of nerves (paralysis); stimulates cough; causes some chronic affections of the skin (with desquamation). Indirect secondary action: treatment of intermittent fever with daily recurrence, useful in hectic and remittent fever, in some types of paralysis, in cough, in similar diseases of the skin. 
Later on, in the "Introduction" to Organon of homeopathic medicine [2], his major work, Hahnemann describes hundreds of examples of involuntary homeopathic cures accomplished by "Old School" doctors. Thus he was able to ground his early observations on the therapeutic similarity principle on hundreds of literature references stemming from different authors. To continue with the example of arsenic above:

"[...] And whence could arise that curative power of arsenic which exhibits in certain species of intermittent fevers, (a virtue attested by so many thousands of examples, but in the practical application of which, sufficient precaution has not yet been observed, and which virtue was asserted centuries ago by Nicholas Myrepsus, and subsequently placed beyond a doubt by the testimony of Slevogt, Molitor, Jacobi, J. C. Bernhardt, Jiingken, Fauve, Brera, Darwin, May, Jackson, and Fowler), if it did not proceed from its peculiar faculty of excit ingfever, as almost every observer of the evils resulting from this substance has remarked, particularly Amatus Lusitanus, Degner, Buchholz, Heun, and Knape. We may confidently believe E. Alexander, when he tells us that arsenic is a sovereign remedy in some cases of angina pectoris, since Tachenius, Guilbert, Preussius, Thilenius, and Pyl, have seen it give rise to very strong oppression of the chest; Gresselius, to a dyspncea approaching even to suffocation; and Majault, in particular, saw it produce sudden attacks of asthma excited by walking, attended with great depression of the vital powers".

In paragraphs 63 to 65 of Organon of medicine [3], Hahnemann explicitly grounds the "mechanism of action of drugs" and the "principle of similitude or similarity" on the drug primary action and the corresponding secondary action or vital reaction of the organism:

"Every agent that acts upon the vitality, every medicine, deranges more or less the vital force, and causes a certain alteration in the health of the individual for a longer or a shorter period. This is termed primary action. [...]. To its action our vital force endeavors to oppose its own energy. This resistant action is a property, is indeed an automatic action of our life-preserving power, which goes by the name of secondary action or counteraction". (Organon of medicine, paragraph 63)

By giving to ill individuals drugs that caused similar symptoms in healthy experimental subjects (similia similibus curentur), application of the therapeutic similarity principle seeks to elicit a healing homeostatic reaction against disease by inducing the organism to react against its own disorders. Described in 1860 by Sorbonne physiologist Claude Bernard as "fixité du milieu intérieur", the term "homeostasis" was minted in 1929 by Harvard physiologist Walter Bradford Cannon to name the tendency or ability of living beings to keep their internal environment constant by means of physiological processes of self-adjustment.

Emphasizing that the organism secondary action (opposed in nature to the drug primary action) is observed "in each and every instance without any exception" with either ponderable or infinitesimal doses in both healthy and ill individuals, Hahnemann raises the similitude principle to the level of "natural law" (Organon of medicine, paragraphs 58,61, 110-112).

Hahnemann had resource to hypothetical syllogism "modus tollens" ("inference by negation" or "indirect proof') to validate the homeopathic treatment method (principle of similitude). In this way, in paragraphs 56 to 67 of Organon of medicine [3] he subjected the so-called enantiopathic or antipathic treatment method (principle of contraries) to critical analysis. Bringing up instances of several drugs contemporarily used on the grounds of their primary action contrary to the patient's symptoms (contraria contrariis curentur), Hahnemann showed that after an initial slight and short-lasting aggravation relief of the thus palliated symptoms always followed "with no exception whatsoever":

"Important symptoms of persistent diseases have never yet been treated with such palliative, antagonistic remedies, without the opposite state, a relapse - indeed, a palpable aggravation of the malady - occurring a few hours afterwards. For a persistent tendency to sleepiness during the day the physician prescribed coffee, whose primary action is to enliven; and when it had exhausted its action the day - somnolence increased; - for 
frequent waking at night he gave in the evening, without heeding the other symptoms of the disease, opium, which by virtue of its primary action produced the same night (stupefied, dull) sleep, but the subsequent nights were still more sleepless than before; [...] - weakness of the bladder, with consequent retention of urine, was sought to be conquered by the antipathic work of cantharides to stimulate the urinary passages whereby evacuation of the urine was certainly at first effected but thereafter the bladder becomes less capable of stimulation and less able to contract, and paralysis of the bladder is imminent; - with large doses of purgative drugs and laxative salts, which excite the bowels to frequent evacuation, it was sought to remove a chronic tendency to constipation, but in the secondary action the bowels became still more confined; [...] How often, in one word, the disease is aggravated, or something even worse is effected by the secondary action of such antagonistic (antipathic) remedies, the old school with its false theories does not perceive, but experience teaches it in a terrible manner". (Organon of medicine, paragraph 59)

In terms of modern scientific reason and physio-pharmacological concepts, the primary action adduced by Hahnemann corresponds to the therapeutic, adverse and side effects of conventional drugs. The secondary action or vital reaction in turn corresponds to the rebound effect or paradoxical reaction of the organism, which has been observed after discontinuation of several classes of drugs that act contrarily to the symptoms of patients (palliative, enantiopathic or antipathic drugs) [4-11].

Analogously to the traditional secondary action of homeopathic medicines, the rebound effect of modern drugs may be used for therapeutic purposes [12-14], namely to stimulate homeostatic healing reactions provided that drugs are prescribed according to the principle of similarity of symptoms as described below.

This article presents the conclusions of a study that sought to develop a method to use modern drugs according to the principle of therapeutic similitude. The first part discusses the validity of the similitude principle on the grounds of scientific evidence on modern drugs rebound effect or paradoxical reaction, and the possibility to consider the adverse effects of conventional drugs as homeopathic pathogenetic effects. The second part describes a homeopathic materia medica and repertory comprising the primary (therapeutic, adverse and side) effects of modern drugs as described in The United States Pharmacopeia Dispensing Information (2004), and illustrates and systematizes their therapeutic application in present-day diseases.

\section{Evidence of similitude in modern pharmacology}

The hypothetic "modus tollens" used by Hahnemann to develop the principle of therapeutic similitude corresponds to the "null hypothesis" of modern statistics. We also applied it in the course of the last fourteen years to the study of the "sad results of the use of antagonistic medicines (principle of contrary)" of modern drugs according to modern physio-pharmacological notions such as rebound effect or paradoxical reaction of the organism (viz., homeopathic model secondary action or vital reaction).

Bridging the gap between the homeopathic principle of treatment and modern pharmacology, countless reports in pharmacological compendia and clinical and experimental trials published in scientific journals point to a secondary reaction of the organism opposing the primary action of a drug, thus confirming Hahnemann's early observations. Such secondary action seeks to maintain organic homeostasis, and is currently known as rebound effect or paradoxical reaction of the organism in conventional pharmacology.

To illustrate: drugs classically used in angina pectoris treatment (beta-blockers, calcium channel blockers, nitrates, etc.) whose primary action is beneficial (anti-angina) might awaken paradoxical increase of the frequency and intensity of chest-pain after discontinuation or irregular use, which sometimes does not respond to any therapeutic means. Drugs used to control arterial hypertension (alpha-2 agonists, betablockers, ACE inhibitors, MAO inhibitors, nitrates, sodium nitroprusside, hydralazine, etc.) might cause rebound arterial hypertension as paradoxical reaction of the organism to the primary stimulus; antiarrhythmic drugs (adenosine, amiodarone, beta-blockers, calcium channel blockers, disopyramide, 
flecainide, lidocaine, mexiletine, moricizine, procainamide, quinidine, digital, etc.) may awaken rebound exacerbation of basal ventricular arrhythmias when treatment is interrupted. Anticoagulant drugs (argatroban, bezafibrate, heparin, salicylates, warfarin, clopidogrel, etc.), employed in the prophylaxis of thrombosis due to their primary effect may promote thrombotic complications as paradoxical reaction of the organism. With the use of psychiatric drugs such as anxiolytics (barbiturates, benzodiazepines, carbamates, etc.), sedative-hypnotics (barbiturates, benzodiazepines, morphine, promethazine, zopiclone, etc.), stimulants of the central nervous system (amphetamines, caffeine, cocaine, mazindol, methylfenidate, etc.), antidepressant (tricyclic, MAO inhibitors, etc.) or antipsychotic (clozapine, phenothiazines, haloperidol, pimozide, etc.) paradoxical reactions of the organism seeking to keep organic homeostasis may be observed associated with the appearance of symptoms contrary to the ones expected from their primary therapeutic use, consequently worsening the initial picture. Drugs with anti-inflammatory primary action (corticoids, ibuprofen, indomethacin, paracetamol, salicylates, etc.) might trigger paradoxical reactions of the organism that increase inflammation and its mediators serum concentration. Drugs with analgesic primary action (caffeine, calcium channels blockers, clonidine, ergotamine, methysergide, opiates, salicylates, etc.) may cause significant hyperalgesia as rebound effect. Diuretics (furosemide, torasemide, triamterene, etc.) enantiopathically used to diminish plasma volume (edema, arterial hypertension, congestive heart failure, etc.) may cause rebound sodium and potassium retention, thus increasing the basal plasma volume. Drugs primarily used as antidyspeptic (antacids, $\mathrm{H}_{2}$ antagonists, misoprostol, sucralfate, etc.) in the treatment of gastritis and gastroduodenal ulcers might promote after a primary decrease of acidity rebound increase of hydrochloric acid production by the stomach eventually causing perforation of chronic gastro-duodenal ulcers. Bronchodilators (adrenergic drugs, sodium chromoglycate, epinephrine, ipratropium, nedocromil, etc.) used in the treatment of bronchial asthma may worsen bronchial constriction as paradoxical response of the organism to the interruption or discontinuation of treatment, etc. [4, 5]

Evidenced by clinical and experimental pharmacology [9, 10], the properties of rebound effect (organism paradoxical reaction) are the same as the homeopathic vital reaction (secondary action) described by Hahnemann (Organon of medicine, paragraphs 59, 64, 69): (i) it appears only in susceptible individuals (around $5 \%$ of the population), whose constitution exhibits symptoms similar to the pathogenetic effects of the drug; (ii) it does not depend on the drug, repetition of doses, or type of symptoms (disease); (iii) it appears after the primary action of the drug (discontinuation) as an automatic manifestation of the organism; (iv) it induces an organic state (symptoms) opposite to and greater in intensity and/or duration than the drug primary action; (v) the size of effect is proportional to the intensity of the primary action of the drug.

As further peculiar characteristics of this phenomenon, rebound effect or paradoxical reaction of the organism manifests itself within a variable period of time (hours to weeks) after interruption or discontinuance of treatment. It also lasts a variable period of time (hours to weeks) as a function of the characteristics of the drug and each patient's idiosyncrasy.

\section{Evidence of similitude in modern drugs fatal iatrogenic events}

Despite countless scientific studies giving evidence of the rebound effect of modern drugs published in high impact factor journals, its mechanism is systematically neglected in teaching or public divulgation contexts. Thus, dismissed as a mere "natural phenomenon" (described by homeopathy more than two centuries ago), countless fatal iatrogenic effects arising from the use of modern enantiopathic drugs that could be avoided by the inclusion of these evidences in modern medical knowledge are not.

Despite the idiosyncratic nature of this phenomenon that appears in about $5 \%$ of individuals (and for this very same reason calls to individualized medicines in homeopathic treatments), contemporary scientific evidences 
point to the occurrence of severe and fatal iatrogenic effects as a function of the organism paradoxical reaction following discontinuance of several classes of modern enantiopathic drugs [6].

Recent meta-analyses showed that due to their primary anticoagulant action all non-steroidal antiinflammatory drugs (NSAIDs), either selective (rofecoxib, celecoxib, etc.) or non-selective (salicylates, diclofenac, naproxen, ibuprofen, etc.) cyclooxygenase inhibitors induce thrombogenic paradoxical reactions after discontinuance leading to significant increase in the incidence of thrombosis and causing fatal vascular events (acute myocardial infarction - AMI, and cerebrovascular accidents - CVA) [7].

Analogously further meta-analyses indicate that after their primary bronchodilator action, long-acting betaagonist bronchodilators (salmeterol, formoterol, etc.) cause significant irreversible and fatal paradoxical bronchospasm [8]. Several studies showed that antidepressant agents selectively inhibiting serotonin reuptake (SISRs) induce rebound exacerbation of suicidal ideas after an initial improvement of this symptom [9]. The same applies to various types of statins (simvastatin, lovastatin, atorvastatin, etc.) resulting in paradoxical and fatal vascular events (AMI, CVA) after primary increase of their pleiotropic or vascular protective effects [10]. Recent research shows that just as other anti-dyspeptic agents, also proton-pump inhibitors (PPIs such as omeprazole, pantoprazole, esomeprazole, etc.) cause rebound hypergastrinemia and acid hypersecretion after initial improvement of gastric acidity, thus exacerbating gastritis and ulcers (perforation of chronic ulcers), gastric cancer, carcinoid tumor and so forth [11].

Compared to placebo, the risk of fatal vascular events was 3.4 times higher after salicylates discontinuance, 1.52 after NSAIDs and 1.67 after rofecoxib discontinuance [7]. Risk of fatal bronchoconstriction was 4 times higher after long-acting bronchodilators discontinuance, and 1/1,000 patients/year/use deaths from rebound bronchospasm, which corresponds to 4,000-5,000 deaths/year only in the USA and 40,000-50,000 worldwide as a function of the widespread use of these agents [8].

Risk of suicidal behavior was 6 times higher after SISRs discontinuance representing about 5 rebound suicidal events per 1,000 teenage-patients/year/use, i.e. 16,500 suicidal ideas or behaviors/year only in teenagers and only in the USA [9]. After statins discontinuation compared to no treatment, the risk of mortality was 1.69 higher and the risk of fatal vascular events was 19 times higher, thus corresponding to hundreds of thousands of episodes due to the widespread use of these agents [10]. In regards to PPIs, $70 \%$ of users report rebound acid hypersecretion [11].

Average time for rebound effect or paradoxical reaction to manifest after treatment discontinuation does not vary among different classes of drugs, e.g. 10 days for salicylates, 14 days for NSAIDs, 9 days for rofecoxib, 7 days for SISRs and 7 days for statins. In regards to anti-dyspeptic agents, rebound acid hypersecretion occurs within 1 hour after a standard antacids dose, 2 days after a 4-week-course of $\mathrm{H}_{2}$-receptor antagonists, and 1 or 2 weeks after a 4- or 8-week PPIs course. Rebound phenomena last 10 days after a 4-week $\mathrm{H}_{2}$-receptor antagonists course, and 2 to 4 weeks after a 4- or 8-week PPIs course. Treatment duration did not show direct correlation with the appearance of rebound effect, however, drugs with intense palliative action, i.e. that significantly suppresses the primary symptoms, of disease exhibit proportional frequency/intensity of paradoxical reactions. [6-11]

\section{Homeopathic pathogenetic trials (HPTs)}

To establish the healing properties of drugs in order to apply the principle of therapeutic similitude, homeopathy employs HPTs as a pharmacological clinical research model. HPTs may be equated to modern "phase I studies" and they take into account all types of primary actions, the so-called pathogenetic (mental, general or physical) effects or symptoms induced by drugs on the state of human health. These very same effects are called therapeutic, adverse or side effects of drugs by modern pharmacology. 
Despite Hahnemann laid down ideal stipulations to carry out HPTs (Organon of medicine, paragraphs 105145), the homeopathic materia medica is actually a compilation of signs and symptoms recorded during the tests of thousands of drugs in both healthy and ill individuals in ponderable (substances in raw state) and diluted (dynamized medicines) doses. Therefore, it comprises pictures of artificial disease states needed to apply the homeopathic therapeutic method. In this regard, it is worth to observe that the historical reviews carried out by Robert Ellis Dudgeon [15] and Richard Hughes [16] show that most symptoms listed in works homeopathic materia medica written by Hahnemann (Fragmenta de viribus medicamentorum, Materia Medica Pura and Chronic Diseases) arise from drugs used in ponderable doses and/or on ill individuals.

Analogously, later homeopaths published new HPTs or additions to the older ones performed in the same manner, from which the following are still employed in present-day homeopathic clinical practice: C. G. C. Hartlaub and C. F. Trinks (Reine Arzneimittellehre, 1828-1831, Germany), George H. G. Jahr (Manual of Homeopathic Medicines, 1835, Germany), Edwin M. Hale (New Remedies, 1867-1873, USA), Timothy F. Allen (The Encyclopedia of Pure Materia Medica, 1874-1879, USA), etc. [15-16]

Accordingly, the next section describes the adverse events of modern drugs that from the homeopathic perspective may be considered primary actions (pathogenetic manifestations) able to induce a healing vital reaction (paradoxical reaction or rebound effect) when applied according to the principle of therapeutic similitude.

\section{Use of adverse events as pathogenetic manifestations of modern drugs}

Adverse events (AE) or reactions (AR) to drugs are defined by the World Health Organization (WHO) [17] as "a response to a drug which is noxious and unintended, and which occurs with doses normally used in man for the prophylaxis, diagnosis, or therapy of disease, or for the modification of physiological function".

During the study of a new drug (phases I to IV) [18], besides the expected therapeutic effect, also adverse events appear (adverse/ side effects), which can be classified according to criteria such as predictability, frequency, intensity, causality and severity [19]. For this study purposes, namely to assimilate the adverse events of modern drugs to pathogenetic effects (new symptoms) of such drugs, the criteria making this relationship evident are predictability, frequency and causality.

According to the criterion of predictability, "predictable" adverse events are the ones already described in the literature (drug monographs); conversely, "unpredictable" adverse events have not yet been reported. This study employed the adverse/ side effects described in drug monographs (The United States Pharmacopeia Dispensing Information - USP DI) [20], therefore they are all "predictable" and are likely to reappear in future trials.

"Predictable" adverse events can be further classified according to their frequency or incidence of expression [21] as: (i) "very common": frequency higher than or equal to 10.0\%; (ii) "common": higher than or equal to $1.0 \%$ and lower than $10.0 \%$; (iii) "not common": higher than or equal to $0.1 \%$ and lower than $1.0 \%$; (iv) "rare": higher than or equal to $0.01 \%$ and lower than $0.1 \%$; and (v) "very rare": lower than $0.01 \%$.

Drugs monographs used in this study (USP DI) [20] classify drugs adverse/side effects according to their frequency in three groups: (i) "more frequent": higher than or equal to 4.0\%; (ii) "less frequent": higher than or equal to $1.0 \%$ and lower than $4.0 \%$; and (iii) "rare": lower than $1.0 \%$.

It is worth to remind here that before any new drug is approved and marketed it must be subjected to phases I to III studies, where their adverse events are observed in thousands of individuals. Phase IV studies conversely refer to the surveillance and vigilance of a drug effects after it entered the market, which extends the observation range to tens of thousands of individuals and also on the long run. Results are then incorporated into the drug monographs, which are periodically updated (USP DI). 
Therefore, the adverse events used in this study as pathogenetic manifestations (new symptoms) of drugs were observed in the lowest frequencies (about 1.0\%) in hundreds of individuals; this fact reinforces the validity of this proposal.

Regarding causality, according to WHO [19, 22] an adverse event is related to a drug according to the following categories: "defined", "probable", "possible", "improbable", "conditional" and "unclassifiable", depending on the degree of certainty of the corresponding interaction. By definition, adverse events whose causality is rated "defined" or "probable" exhibit: temporal sequence (i.e., there is temporal connection between the administration of the drug and appearance of adverse events); typical reaction; they disappear when the drug is discontinued; and cannot be explained out of the underlying disease or other therapeutic means.

The causal link between a drug and an adverse event (risk evaluation) is retrospectively established as causeeffect. "Predictable" and "quantified" (i.e. determined frequency) have "probable causality" [19]. For this reason, the adverse/side effects used in this study (USP DI) exhibit evident causal relationship with the corresponding drugs (predicted risk) and thus are "new symptoms belonging to the drug", as Hahnemann stipulated in paragraph 142 of Organon of medicine [3].

\section{Homeopathic use of modern drugs: therapeutic application of the rebound effect}

Some instances of involuntary homeopathic cures with conventional drugs are reported in the scientific literature. Biphasic contraceptives (anteovin) were used to induce rebound ovulation and consequent pregnancy in women with functional sterility; central nervous systems stimulants (methylphenidate) were used to calm down and improve attention in children with attention deficit hyperactivity disorder (ADHD); gonadotropin releasing hormone stimulants (leuprorelin) were used in the treatment of testosteronedependent prostate tumors; immunosuppressant agents (thiomorpholine analogous to prazosin) induced rebound immune-stimulation after primary immunosuppression, and so forth $[4,5]$.

Retracing classic homeopathy steps to conclude an earlier stage of this research [12-14], this author systematized the use of modern drugs according to the principle of therapeutic similitude. This is, we suggest stimulating the organism's healing rebound effect or paradoxical reaction (vital reaction) by using drugs (in infinitesimal doses) that caused similar symptoms in healthy or ill individuals.

To make this proposal operative a Homeopathic Materia Medica of Modern Drugs grouping together all primary (therapeutic, adverse and side) effects of drugs (USP DI) according to the traditional chapters scheme of the homeopathic materia medica was needed. At the same time, special value was attributed to the frequency of appearance of symptoms during the different phases of the study of drugs.

To facilitate actual selection of an individualized medicine (similar to the patient's totality of symptoms) which is the basic premise for successful homeopathic treatment - the second stage involved the elaboration of a Homeopathic Repertory of Modern Drugs, where symptoms and their corresponding remedies are arranged as in the classic homeopathic repertories.

\section{Homeopathic Materia Medica of Modern Drugs (HMMMD)}

As initial source for HMMMD The United States Pharmacopoeia Dispensing Information (USP DI, 2004) was chosen because its information is reliable and it bears no conflict of interests with the pharmaceutical industry. 
All primary (pathogenetic manifestations), viz. therapeutic, adverse and side effects of each drug were systematized according to the traditional homeopathic materia medica pattern and allocated to the corresponding chapter: Mind; Vertigo; Head; Eye; Vision; Ear; Hearing; Nose; Face; Mouth; Teeth; Throat; External Throat; Stomach; Abdomen; Rectum; Stool; Bladder; Kidneys; Prostate Gland; Urethra; Urine; Genitalia Male; Genitalia Female; Larynx and Trachea; Language, Conversation and Voice; Respiration; Cough; Expectoration; Chest; Back; Extremities; Nails; Sleep; Dreams; Chill; Fever; Perspiration; Skin e Generalities. Diagnostic Tests were grouped together in a new chapter.

According to the homeopathic tradition and in conformity with the classification of adverse events mentioned above [20,21], "frequency of incidence" of pathogenetic symptoms (therapeutic, adverse and side effects) was scored; these scores (points) are represented in the text with different fonts: "very frequent" (therapeutic effects) / 5 points / bold italic font; "more frequent" $(\geq 4 \%) / 4$ points / bold font; "less frequent" $(\geq 1 \%$ and $<4 \%)$ / 3 points / italic underlined font; "rare" (<1\%) / 2 points / italic font; "overdose"/ 1 point / normal font.

In HMMMD, syndromes (viz., modern clinical diagnoses) were kept as such, whereas their constituting symptoms were distributed among the respective chapters of the HRMD. This study systematized the pathogenetic effects (symptoms) of 1,251 modern drugs according to the homeopathic model allowing for their therapeutic application on the grounds of the principle of similarity. The overall structure is illustrated by the example of PPI drug "pantoprazole" (Table 1).

\section{Table 1. Example of systematization of pathogenetic effects in HMMMD}

\begin{tabular}{|c|c|}
\hline \multicolumn{2}{|c|}{ Pantoprazole (Gastric acid pump inhibitor) } \\
\hline Chapters & Primary actions or pathogenetic effects \\
\hline Mind & anxiety; confusion \\
\hline Vertigo & $\begin{array}{l}\text { dizziness; } \underline{\text { vertigo }} \text { (dizziness; feeling of constant movement of self or surroundings; sensation } \\
\text { of spinning) }\end{array}$ \\
\hline Head & headache; migraine \\
\hline Vision & Blurred vision \\
\hline Eye & $\begin{array}{l}\text { angioedema (large, hive-like swellings on eyelids); neuropathy, optic, anterior ischemic } \\
\text { (blindness; blurred vision; decreased vision; loss of vision, sudden) }\end{array}$ \\
\hline Vision & $\underline{\text { blurred vision }}$ \\
\hline Hearing & tinnitus (ringing or buzzing in the ears) \\
\hline Nose & $\begin{array}{l}\text { rhinitis (runny or stuffy nose); sinusitis (aching, fullness, or tension in area of affected } \\
\text { sinus; headache; runny nose) }\end{array}$ \\
\hline Face & angioedema (large, hive-like swellings on face, lips) \\
\hline Mouth & $\begin{array}{l}\text { angioedema (large, hive-like swellings on mouth, and/or tongue); salivation, increased; } \\
\text { speech disorder (difficulty in speaking) }\end{array}$ \\
\hline Throat & pharyngitis (sore throat) \\
\hline $\begin{array}{l}\text { External } \\
\text { Throat }\end{array}$ & pain, neck \\
\hline Stomach & $\begin{array}{l}\text { belching; } \underline{\text { dyspepsia }} \text { (indigestion); gastroenteritis (abdominal pain; anorexia; diarrhea; } \\
\text { nausea; weakness); } \underline{\text { nausea }} \text {; vomiting }\end{array}$ \\
\hline
\end{tabular}




\begin{tabular}{|c|c|}
\hline Abdomen & $\begin{array}{l}\text { flatulence; gastroenteritis (abdominal pain; anorexia; diarrhea; nausea; weakness); pain, } \\
\text { abdominal; pancreatitis (abdominal pain; nausea; vomiting); failure, hepatic (headache; } \\
\text { stomach pain; continuing vomiting; dark-colored urine; general feeling of tiredness or } \\
\text { weakness; light-colored stools; yellow eyes or skin) }\end{array}$ \\
\hline Rectum & diarrhea; rectal disorders \\
\hline Bladder & infection, urinary tract (difficulty in urinating; frequent urge to urinate; painful urination) \\
\hline Kidneys & $\begin{array}{l}\text { nephritis, interstitial (bloody or cloudy urine; fever; skin rash; swelling of feet or lower legs; } \\
\text { greatly decreased frequency of urination or amount of urine) }\end{array}$ \\
\hline Respiration & $\begin{array}{l}\text { bronchitis (chills; cough; headache; hoarseness); dyspnea (shortness of breath); infection, } \\
\text { upper respiratory tract (cough; runny or stuffy nose; sore throat) }\end{array}$ \\
\hline Cough & cough, increased \\
\hline Chest & $\begin{array}{l}\text { bronchitis (chills; cough; headache; hoarseness); pain, chest; tachycardia, mild (fast, } \\
\text { pounding, or irregular heartbeat or pulse) }\end{array}$ \\
\hline Back & pain, back \\
\hline Extremities & arthralgia (pain in joints); hypertonia (muscle rigidity or stiffness) \\
\hline Sleep & insomnia (trouble in sleeping) \\
\hline Skin & $\begin{array}{l}\text { erythema multiforme (pain in joints or muscles; itching or redness of skin; bull's eye-like } \\
\text { lesion on skin); } \text { itching; necrolysis, epidermal, toxic (itching or redness of skin; loosening } \\
\text { and/or stripping off of top layer of skin; skin tenderness with burning); } \underline{\text { rash }}\end{array}$ \\
\hline Generalities & $\begin{array}{l}\text { anaphylaxis (changes in facial skin color; fast or irregular breathing; puffiness or swelling } \\
\text { of the eyelids or around the eyes; shortness of breath, troubled breathing, tightness in } \\
\text { chest, and/or wheezing; skin rash, hives, and itching); angioedema; asthenia (loss of energy } \\
\text { or strength; weakness); } \text { erythema multiforme (pain in joints or muscles; itching or redness } \\
\text { of skin; bull's eye-like lesion on skin); flu-like syndrome (abdominal pain; chills; cough; } \\
\text { headache; pain in joints or muscles; runny nose; sneezing; sore throat); hyperglycemia } \\
\text { (increased frequency and volume of urination; unusual thirst); hypokinesia (difficulty in } \\
\text { moving); infection; injection site reaction (bleeding; blistering; burning; coldness; } \\
\text { discoloration of skin; feeling of pressure; hives; infection; inflammation; itching; lumps; } \\
\text { numbness; pain; rash; redness; scarring; soreness; stinging; swelling; tenderness; tingling; } \\
\text { ulceration; warmth); jaundice (yellow eyes or skin); pain; Stevens-Johnson syndrome } \\
\text { (aching joints and muscles; blistering, loosening, peeling, or redness of skin; unusual } \\
\text { tiredness or weakness); pancytopenia (high fever; chills; unexplained bleeding or bruising; } \\
\text { bloody, black, or tarry stools; pale skin; unusual tiredness or weakness; cough; shortness of } \\
\text { breath; sores, ulcers, or white spots on lips or in mouth; swollen glands); rhabdomyolysis } \\
\text { (dark-colored urine; fever; muscle cramps or spasms; muscle pain or stiffness; unusual } \\
\text { tiredness or weakness); vasodilation (feeling of warmth or heat; flushing or redness of skin, } \\
\text { especially on face and neck; headache; feeling faint, dizzy, or lightheaded; sweating) }\end{array}$ \\
\hline
\end{tabular}

\section{Homeopathic Repertory of Modern Drugs (HRMD)}

The pathogenetic symptoms listed in the HMMMD were distributed following the traditional model of homeopathic repertories. Thus, the same arrangement of chapters was followed, and all drugs inducing a same symptom are grouped together under rubrics and sub-rubrics. Drugs are mentioned by the abbreviation of its name and different fonts indicate their score of relative "frequency of incidence". To facilitate the search of the most accurate rubric in all chapters, "crossed-references" point to similar pathogenetic manifestations. 
The overall structure is illustrated by the example of rubric "cancer", included in HRMD chapter "Generalities" (Table 2).

Table 2. Example of symptoms description in HRMD (Chapter Generalities)

\section{Cancer (See Tumors)}

- breast: DrosE-syst., Estro-syst.

- invasive: EstroPO-syst.

- carcinoma

- breast: Adal-syst.

- gastrointestinal: Adal-syst.

- hepatocellular: AnabS-syst., DrosEE-syst., EstroPO-syst.

- women having a predisposing or pre-existing condition, especially those who smoke tobacco: DrosEE-syst., EstroPO-syst.

- liver: Cyp-syst.

- prostatic carcinoma disease flare, transient: Gos-syst.

- skin: Adal-syst.

- squamous: Imiq-top.

- urogenital: Adal-syst.

- endometrial: ConjE-syst., DrosE-syst., Estro-syst., Estro-vag.

- leukemia (bone pain): AnabS-syst.

- myeloid or myelogenous, acute (bone pain): Docet-syst., $\underline{\text { Ibr-syst. }}$

- non-lymphocytic, acute (tiredness; weakness): Clod-syst.

- promyelocytic leukemia (APL) differentiation syndrome, acute: $\underline{\operatorname{Ars} T r \text {-syst. }}$

- secondary: Epir-syst.

- lymphoid syndromes (including lymphoid hyperplasia, pseudolymphomas, and pseudopseudolymphomas): AntconH-syst. [Phenytoin]

- lymphoma: Adal-syst., AntthyGR-syst., Cyclosp-syst., Etan-syst.

- increase in the incidence of: AntthyGR-syst.

- lymphoma like reaction: Adal-syst.

- post-transplant lymphoproliferative disease (PTLD), increase in the incidence of: AntthyGRsyst.

- malignancies: Alef-syst., Etan-syst.

- neuroblastoma: DiphtTTH-syst.

- ovarian: ConjE-syst.

- skin, non-melanoma: Etan-syst.

Adal-syst.: Adalimumab (Systemic); Alef-syst.: Alefacept (Systemic); AnabS-syst.: Anabolic Steroids (Systemic); AntconH-syst. [Phenytoin]: Anticonvulsants, Hydantoin (Systemic) [Phenytoin]; AntthyGR-syst.: Anti-thymocyte Globulin (Rabbit) (Systemic); ArsTr-syst.: Arsenic Trioxide (Systemic); Clod-syst.: Clodronate (Systemic); ConjE-syst.: Conjugated Estrogens and Medroxyprogesterone For Ovarian Hormone Therapy (OHT) (Systemic); Cyclosp-syst.: Cyclosporine (Systemic); Cyp-syst.: Cyproterone (Systemic); DiphtTTH-syst: Diphtheria and Tetanus Toxoids and Acellular Pertussis Adsorbed and Hepatitis B (Recombinant) and Inactivated Poliovirus Vaccine Combined (Systemic); Docet-syst.: Docetaxel (Systemic); DrosE-syst.: Drospirenone and Estradiol (Systemic); DrosEE-syst.: Drospirenone and Ethinyl Estradiol (Systemic); Epirsyst.: Epirubicin (Systemic); Estro-syst.: Estrogens (Systemic); Estro-vag.: Estrogens (Vaginal); EstroPO-syst. 
Estrogens and Progestins Oral Contraceptives (Systemic); Etan-syst.: Etanercept (Systemic); Gos-syst.: Goserelin (Systemic); Ibr-syst. Ibritumomab Tiuxetan (Systemic);_Imiq-top.: Imiquimod (Topical).

\section{Conclusion}

Applying the "modus tollens" hypothetic syllogism initially used by Hahnemann to give scientific grounds to homeopathic therapeutics, this author devoted the last fourteen years to ground the principle of therapeutic similitude on the phenomenon of rebound effect or paradoxical reaction of modern drugs. The first phase of this study comprised a thorough review of the literature on clinical and experimental pharmacology studies. The second stage consisted in developing a method to employ modern drugs according to therapeutic similitude, which resulted in a proposal to include 1,251 new drugs in the homeopathic materia medica.

Although ideally HPTs ought to be performed with drugs in infinitesimal doses administered to healthy individuals to avoid confusing true pathogenetic effects and symptoms of disease, the traditional works on homeopathic materia medica compile together signs and symptoms recorded in tests of drugs on healthy and ill individuals and induced by both ponderable and infinitesimal doses. Thus, they contain all the pictures of artificial disease states needed to apply the principle of therapeutic similarity. In the clinical research of new drugs (phase I to IV studies) the aspects of predictability, frequency and causality of adverse events described in monographs indicate that they also are pathogenetic manifestations (new symptoms) of drugs, thus endorsing their use according to the principle of similitude.

In order to widen the range of application of therapeutic similitude to hundreds of new drugs tested on thousands of individuals according to strict protocols, a HMMMD and a HRMD were elaborated following the homeopathic traditional model. In the former, the symptoms of each drug were distributed in chapters following the classic homeopathic model and scored according to their relative frequency of appearance. In the latter, chapters group together all drugs inducing a same symptom with their corresponding score. It will be thus possible to employ new drugs to relieve clinical disorders commonly treated by homeopathy as well as modern signs, symptoms and complex syndromes (Table 3).

This research project is titled "New Homeopathic Medicines: use of modern drugs according to the principle of similitude", and it is distributed in three volumes: (1) Scientific Basis of Principle of Similitude in Modern Pharmacology; (2) Homeopathic Materia Medica of Modern Drugs; and (3) Homeopathic Repertory of Modern Drugs.

Aiming at divulgating this project among homeopaths worldwide as well as to allow for its improvement, the full materials are posted online, initially in English and Portuguese at www.newhomeopathicmedicines.com [23].

Thus, concluding a study began in 1997 [4,5], all studies on this subject will be grouped in the project materials in the hope of widening the scientific basis of homeopathy and the homeopathic treatment of modern diseases.

Table 3. Examples of homeopathic therapeutic use of conventional drugs

\begin{tabular}{|l|l|}
\hline Chapters & Homeopathic therapeutic use of conventional drugs \\
\hline Mind & $\begin{array}{l}\text { Anxiety, delirium, dementia, depression, forgetfulness, hyperactivity, irritability, } \\
\text { lethargy, mania, panic, schizophrenia, suicidal disposition, etc. }\end{array}$ \\
\hline Vertigo & Dizziness, faintness, gait disorders, lightheadedness, orthostatic hypotension, syncope, \\
\hline & 348 \\
https://doi.org/10.51910/ijhdr.v10i37.456
\end{tabular}




\begin{tabular}{|c|c|}
\hline & unsteadiness, vertigo, etc. \\
\hline Head & $\begin{array}{l}\text { Aneurysm, arteritis, encephalitis, headache, intracranial hypertension, meningitis, } \\
\text { migraine, seborrhea, stroke, etc. }\end{array}$ \\
\hline Eye & $\begin{array}{l}\text { Astigmatism, cataract, cornea disorders, glaucoma, inflammations, keratopathy, } \\
\text { necrosis, neuritis, papilledema, retina disorders, etc. }\end{array}$ \\
\hline Vision & $\begin{array}{l}\text { Amblyopia, blindness, blurred, diplopia, hypermetropia, myopia, presbyopia, scotoma, } \\
\text { etc. }\end{array}$ \\
\hline Hearing & Buzzing, deafness, hyperacusis, hypoacusis, ringing, tinnitus, etc. \\
\hline Nose & Congestion, coryza, dryness, epistaxis, rhinitis, sinusitis, sneezing, etc. \\
\hline Face & Gestures, heat flushes, hirsutism, neuritis, paralysis, swelling, trismus, etc. \\
\hline Mouth & $\begin{array}{l}\text { Bleeding, dryness, gingivitis, glossitis, mucositis, sialorrhea, speech disorders, stomatitis, } \\
\text { taste disorders, ulcers, etc. }\end{array}$ \\
\hline Throat & Angioedema, dryness, dysphagia, esophagitis, pharyngitis, ulcers, etc. \\
\hline External throat & Goiter, hyperthyroidism, hypothyroidism, lymphadenopathy, parotitis, torticollis, etc. \\
\hline Stomach & $\begin{array}{l}\text { Anorexia, dyspepsia, gastritis, gastroenteritis, hemorrhage, hiccough, nausea, polydipsia, } \\
\text { reflux, ulcers, vomiting, etc. }\end{array}$ \\
\hline Abdomen & $\begin{array}{l}\text { Ascites, appendicitis, cholelithiasis, colitis, gastroenteritis, hemorrhage, hepatic } \\
\text { insufficiency, hepatitis, hepatomegaly, inflammatory bowel disease, intestinal } \\
\text { obstruction, pancreatitis, peritonitis, splenomegaly, tumors, etc. }\end{array}$ \\
\hline Rectum & Constipation, diarrhea, hemorrhage, hemorrhoids, mucositis, tenesmus, etc. \\
\hline Bladder & Hemorrhage, infection urinary tract, urinary disorders, etc. \\
\hline Kidneys & $\begin{array}{l}\text { Calculi, glomerulonephritis, pyelonephritis, renal insufficiency, tubular disorders, } \\
\text { urinary disorders, etc. }\end{array}$ \\
\hline Urine & $\begin{array}{l}\text { Acetonuria, albuminuria, glycosuria, hematuria, oliguria, polyuria, proteinuria, pyuria, } \\
\text { sediment, etc. }\end{array}$ \\
\hline Genitalia male & $\begin{array}{l}\text { Atrophy testes, desire sexual disorders, function sexual disorders (ejaculation; erection; } \\
\text { fertility; orgasm), inflammation, etc. }\end{array}$ \\
\hline Genitalia female & $\begin{array}{l}\text { Abortion, cancer, desire and function sexual disorders, hormonal dysfunctions, } \\
\text { inflammation, disorders of (lactation, menses, ovaries, uterus), tumors, etc. }\end{array}$ \\
\hline $\begin{array}{l}\text { Larynx } \\
\text { Trachea }\end{array}$ & Inflammation, laryngismus, edema (glottis, larynx), etc. \\
\hline Respiration & $\begin{array}{l}\text { Accelerated, arrested, asthma, breathing, bronchitis, distress, dyspnea, insufficiency, } \\
\text { impeded, infection, irregular, slow, sounds, wheezing, etc. }\end{array}$ \\
\hline Chest & $\begin{array}{l}\text { Acute myocardial infarction, angina, arrhythmias, heart failure, effusion pleural, } \\
\text { inflammation (alveolitis, endocarditis, pneumonitis, pericarditis, pleuritis), pulmonary } \\
\text { (edema, embolism, fibrosis), etc. }\end{array}$ \\
\hline Extremities & $\begin{array}{l}\text { Ataxia, gout, incoordination, inflammation (arthritis, myositis, neuritis, phlebitis, } \\
\text { tendinitis), myopathy, neuropathy, osteoporosis, paralysis, stiffness, weakness, etc. }\end{array}$ \\
\hline Generalities & $\begin{array}{l}\text { Anaphylaxis, anemia, coma, convulsions, demyelinating disorders, diabetes, } \\
\text { encephalopathy, hypertension, hyperthermia, lymphadenopathy, neuropathy, Stevens- } \\
\text { Johnson's syndrome, thromboembolism, etc. }\end{array}$ \\
\hline
\end{tabular}

\section{References}

[1] Hahnemann S. Essay on a new principle for ascertaining the curative power of drugs, with a few glances at those hitherto employed. In: Dudgeon RE. The lesser writings of Samuel Hahnemann. New Delhi: B. Jain Publishers; 1995 (Reprint edition).

[2] Hahnemann S. Organon of homeopathic medicine. Third American edition. English version of the fifth German edition. New York: William Radde; 1849. 
[3] Hahnemann S. Organon of medicine. 6th edition. (Translated by William Boericke). New Delhi: B Jain Publishers; 1991.

[4] Teixeira MZ. Semelhante cura semelhante: o princípio de cura homeopático fundamentado pela racionalidade médica e científica [Similar cure similar: the homeopathic healing principle based by medical and scientific rationality]. São Paulo: Editorial Petrus; 1998.

[5] Teixeira MZ. Similitude in modern pharmacology. Homeopathy. 1999; 88:112-120.

[6] Teixeira MZ. Evidence of the principle of similitude in modern fatal iatrogenic events. Homeopathy. 2006; 95:229-236.

[7] Teixeira MZ. NSAIDs, Myocardial infarction, rebound effect and similitude. Homeopathy. 2007; 96:67-68.

[8] Teixeira MZ. Bronchodilators, fatal asthma, rebound effect and similitude. Homeopathy. 2007; 96:135-137.

[9] Teixeira MZ. Antidepressants, suicidality and rebound effect: evidence of similitude? Homeopathy. 2009; 98:114-121.

[10] Teixeira MZ. Statins withdrawal, vascular complications, rebound effect and similitude. Homeopathy. 2010; 99:255-262.

[11] Teixeira MZ. Rebound acid hypersecretion after withdrawal of gastric acid suppressing drugs: new evidence of similitude. Homeopathy. 2011; 100:148-156.

[12] Teixeira MZ. Homeopathic use of modern medicines: utilisation of the curative rebound effect. Med Hypotheses. 2003; 60:276-283.

[13] Teixeira MZ. 'Paradoxical strategy for treating chronic diseases': a therapeutic model used in homeopathy for more than two centuries. Homeopathy. 2005; 94:265-266.

[14] Teixeira MZ. New homeopathic medicines: use of modern drugs according to the principle of similitude. Homeopathy 2011; 100:244-252.

[15] Dudgeon RE. Lectures on the theory and practice of homoeopathy. New Delhi: B Jain Publishers; 1982 (Reprint edition). Lectures VII e XII.

[16] Hughes R. A manual of pharmacodynamics. $6^{\text {th }}$ ed. New Delhi: B Jain Publishers; 1980 (Second reprint edition). Lecture II.

[17] World Health Organization (WHO). The Uppsala Monitoring Centre. The importance of pharmacovigilance. Safety monitoring of medicinal products; 2002.

[18] United States. Code of Federal Regulations. 21 CFR. Food and drugs. 312 Investigational new drug application. Washington; $2003 . \quad$ Available at: http://www.accessdata.fda.gov/scripts/cdrh/cfdocs/cfcfr/cfrsearch.cfm?cfrpart=312.

[19] Marodin G, Goldim JR. Confusions and ambiguities in the classification of adverse events in the clinical research. Rev Esc Enferm USP. 2009; 43:690-696. Available at: http://www.scielo.br/pdf/reeusp/v43n3/en_a27v43n3.pdf.

[20] The United States Pharmacopeial Convention. The United States Pharmacopeia Dispensing Information. Easton: Mack Printing Co; 2004. 
[21] World Health Organization (WHO). Council for International Organizations of Medical Sciences. Guidelines for preparing core clinical safety information on drug from CIOMS Working Group III. Geneva; 1995. Available at: https://apps.who.int/dsa/cat98/zcioms8.htm.

[22] World Health Organization (WHO). The Uppsala Monitoring Centre. Safety monitoring of medicinal products. Guidelines for setting up and running a Pharmacovigilance Centre; 2000. Available at: http://apps.who.int/medicinedocs/en/d/Jh2934e/.

[23] Teixeira MZ. New homeopathic medicines: use of modern drugs according to the principle of similitude. São Paulo: Marcus Zulian Teixeira; 2010. 3v. Available at: www.newhomeopathicmedicines.com.

\title{
Uso homeopático de drogas modernas: aplicação terapêutica da reação paradoxal do organismo ou efeito rebote
}

\begin{abstract}
RESUMO
Quando Samuel Hahnemann sistematizou a homeopatia e o efeito das drogas no estado de saúde humano, descreveu uma ação primária das drogas seguida pela ação secundária e oposta do organismo. Visando utilizar essa ação secundária ou reação vital do organismo como método terapêutico, ele postulou o princípio da similitude, ou seja, a administração ao doente de drogas que causam sintomas similares no indivíduo sadio (similia similibus curentur). Na farmacologia moderna, a ação secundária (reação vital) das drogas é conhecida como efeito rebote ou reação paradoxal do organismo. Este fenômeno tem sido observado após a interrupção de vários tipos de drogas paliativas (enantiopáticas), ou seja, aquelas que agem de acordo com o princípio dos contrários (contraria contrariis curentur). Podendo provocar eventos iatrogênicos severos e fatais, o efeito rebote também pode desencadear uma reação curativa quando a mesma droga é utilizada de acordo com o princípio da similitude. A validade do princípio da similitude é assim comprovada pela evidência científica do efeito rebote, e os efeitos primários (terapêuticos, adversos e colaterais) das drogas convencionais podem ser comparados a manifestações patogenéticas e, portanto, serem utilizados homeopaticamente. Para tanto, foi elaborada uma matéria médica e um repertório incluindo 1.251 drogas modernas com base nas monografias descritas em The United States Pharmacopeia Dispensing Information(www.newhomeopathicmedicines.com). Assim, o escopo terapêutico da homeopatia é alargado através da adição de centenas de novos medicamentos que podem ser utilizados em todos os tipos de doenças, incluindo as síndromes clínicas modernas.
\end{abstract}

Palavras-chave: Homeopatia; Mecanismo de Ação dos Medicamentos Homeopáticos; Ação Farmacodinâmica dos Medicamentos Homeopáticos; Medicamentos Homeopáticos, Novos; Efeito Secundário; Efeito Rebote; Reação Paradoxal.

\section{Uso homeopático de fármacos modernos: aplicación terapéutica de la reacción paradojal del organismo o efecto rebote}

\section{RESUMEN}

Cuando Samuel Hahnemann sistematizó la homeopatía y los efectos de los fármacos en el estado de salud humana, describió la acción primaria de los fármacos que es seguida por la reacción secundaria y opuesta del organismo. Objetivando utilizar esta acción secundaria o reacción vital del organismo como método terapéutico, postuló el principio de semejanza, es decir, la prescripción a los enfermos de fármacos que causan síntomas similares en los sanos (similia similibus curentur). En farmacología moderna, esta acción secundaria (reacción vital) es conocida como efecto rebote o reacción paradojal del organismo. Ha sido observada después de la 
interrupción de varias clases de fármacos paliativos (enantiopáticos), o sea, los que actúan según el principio de los contrarios (contraria contrariis curentur). Aunque en este caso se asocie con eventos iatrogénicos severos y fatales, el efecto rebote puede desencadenar una reacción curativa cuando el mismo fármaco es utilizado según el principio de semejanza. La validez del principio de semejanza es por consiguiente probada por la evidencia científica referida al efecto rebote, y los efectos primarios de los fármacos convencionales (terapéuticos, adversos y colaterales) pueden ser equiparados a manifestaciones patogenéticas y ser utilizados homeopáticamente. Para ello, fue elaborada una materia médica y un repertorio incluyendo 1.251 fármacos modernos con base en las monografías descriptas en The United States Pharmacopeia Dispensing Information (www.newhomeopathicmedicines.com). De este modo, el campo terapéutico de la homeopatía es extendido mediante la adición de centenas de nuevos medicamentos que pueden ser utilizados en toda clase de enfermedad incluyendo los innúmeros síndromes clínicos modernos.

Palabras-clave: Homeopatía; Mecanismo de Acción de los Medicamentos Homeopáticos; Acción Farmacodinámica de los Medicamentos Homeopáticos; Medicamentos Homeopáticos, Nuevos; Efecto Secundario; Efecto Rebote; Reacción Paradojal.

\section{(c)) BY-NC-ND Licensed to GIRI}

Support: authors declare that this study received no funding

Conflict of interest: authors declare there is no conflict of interest

Received: 29 July 2011; Revised: 29 November 2011; Published: 20 December 2011.

Correspondence author: Marcus Zulian Teixeira, marcus@homeozulian.med.br, www.homeozulian.med.br .

How to cite this article: Teixeira MZ. Homeopathic use of modern drugs: therapeutic application of the organism paradoxical reaction or rebound effect. Int J High Dilution Res [online]. 2011 [cited YYYY Month dd]; 10(37): 338-352. Available from: http://www.feg.unesp.br/ ojs/index.php/ijhdr/article/view/456/542 